\title{
Opinion 53
}

\section{Rejection of the Species Name Mycobacterium marianum Penso 1953}

Editorial Secretary for the Judicial Commission of the International Committee on Systematic Bacteriology

The Judicial Commission places the species name Mycobacterium marianum on the list of nomina rejicienda as a nomen perplexum because it is a source of confusion.

Wayne (3) pointed out that the name Mycobacterium marianum Penso 1953 was a source of confusion because of its orthographic similarity to Mycobacterium marinum Aronson 1926, despite the fact that the two epithets are derived from quite different roots. The name $M$. mar. inum is widely used for an accepted species of Mycobacterium, whereas $M$. marianum is infrequently employed. He asked that the latter name be held to be a nomen perplexum under Rule 57a (1).

The Judicial Commission considered the request of Wayne, and accepted that the name $M$. marianum was a cause of sufficient confusion to justify placing it on the list of rejected names. The Commission therefore issues the following Opinion.

Opinion 53. The species name Mycobacte- rium marianum Penso 1953 is placed on the list of nomina rejicienda as a nomen perplexum because it is a source of confusion.

\section{LITERATURE CITED}

1. Lapage, S. P., P. H. A. Sneath, E. F. Lessel, V. B. D. Skerman, H. P. R. Seeliger, and W. A. Clark (ed.). 1975. International code of nomenclature of bacteria, 1976 revision. American Society for Microbiology, Washington, D.C.

2. Penso, G. 1953. Criteri generali par determinare la posizione sistematica di un micobatterio p. 89-101. In VI Congr. of Int. Microbiol.: Atti del V Symposium: Actinomycetales, Morfologia, Biologia e Sistematics. Istituto Superiore di Sanita, Rome.

3. Wayne, L. G. 1975. Proposal to reject the specific epithet marianum in the name Mycobacterium marianum Penso 1953 and to conserve the specific epithet scrofulaceum in the name Mycobacterium scrofulaceum Prissick and Masson 1956. Request for an opinion. Int. J. Syst. Bacteriol. 25:230-231. 